\title{
Hydrodynamic sorting controls the transport and hampers source identification of terrigenous organic matter: A case study in East China Sea inner shelf and its implication
}

\author{
Yinli Ji a , Lijuan Feng a , Dahai Zhang a , Qianqian Wang a , Gang Pan ${ }^{\text {b,c }}$, Xianguo Li ${ }^{\text {a,* }}$ \\ a Key Laboratory of Marine Chemistry Theory and Technology (Ocean University of China), Ministry of Education, Qingdao 266100, China \\ ${ }^{\mathrm{b}}$ Research Center for Eco-Environmental Sciences, Chinese Academy of Sciences, Beijing 100085, China \\ ' School of Animal, Rural, and Environmental Sciences, Nottingham Trent University, Nottingham NG25 0QF, UK
}

\section{H I G H L I G H T S}

- Hydrodynamic sorting affects the partitioning of $C$ lignin phenols in sediments.

- This nature of $C$ lignin phenols hampers identification of vegetation type.

- Along shelf transport of sediments has seasonal variations.

- Cross shelf transport of sediments is complicated.

\section{GRA P H I C A L A B S T R A C T}

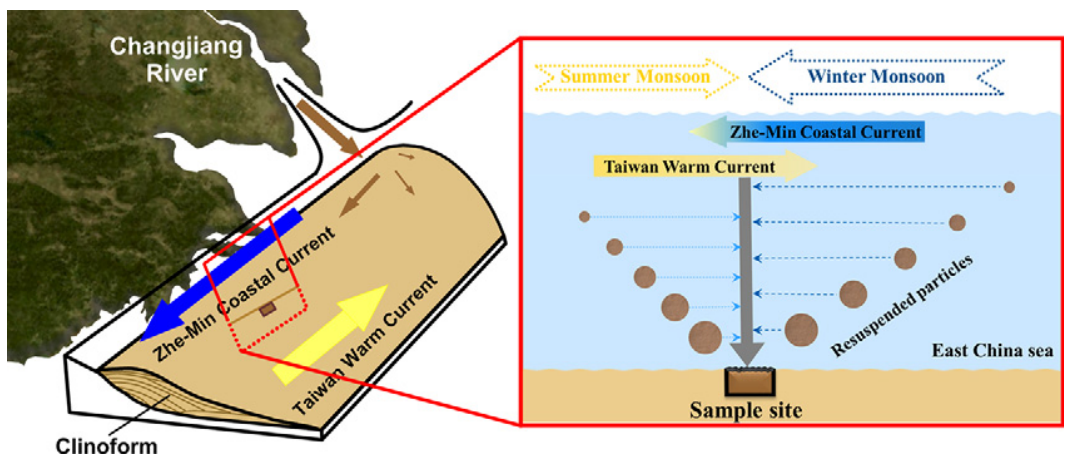

\section{A B S T R A C T}

Transport of terrigenous organic matter (TerOM) in marginal seas plays an important role in marine carbon cycle which is closely related to global climate change. Suspended particulates in East China Sea (ECS) inner shelf are subject to strong influence of seasonally varied Zhe-Min Coastal Current (ZMCC) and Taiwan Warm Current (TWC). Transport of TerOM attached to the mineral particulates is therefore largely dependent on these hydrodynamic conditions. To address the transport pattern of TerOM in highly dynamic marginal seas and its implication, sediment samples were collected from ECS inner shelf and fractionated by water elutriation to simulate the hydrodynamic sorting process. Lignin phenols were determined for each fraction. The abundance of $C$ phenols preferentially concentrated in the finer fractions, which is believed as a collective effect of hydrodynamic sorting, diagenetic reactivity and association preference of $C$ phenols with finer sediments. In contrast to the expectation, sediments at the southernmost site did not have the highest mass percentage for the finest fraction, the lowest lignin abundance and the highest degradation status. Combining the results of lignin parameters with seawater temperature and salinity profiles, it is proposed that sediments are transported along the inner shelf southward in winter and northward in summer to some extent with the influence of seasonally varied ZMCC and TWC, induced by the seasonality of East Asia Monsoon (EAM). Finer grained sediments are more susceptible to this process. This transport pattern, which was only reported previously in ocean modeling, was firstly supported by the observation of lignin biomarkers. It is suggested that cross-shelf transport of sediments in ECS seems to be

\footnotetext{
* Corresponding author.

E-mail address: lixg@ouc.edu.cn (X. Li).
} 
possible, but is complicated and is also affected by the seasonal variation of EAM. This study improved the understanding of hydrodynamic sorting on the transport of TerOM and carbon cycling in the marine system.

Crown Copyright $\odot 2018$ Published by Elsevier B.V. All rights reserved.

\section{Introduction}

The East China Sea (ECS), characterized by a shallow but very broad continental shelf, is one of the largest shelf seas and an important sink of terrestrial organic matter (TerOM) in the world (Shan et al., 2018; Wang et al., 2008; Zhu et al., 2011a). It is one of the typical large riverdominated marginal seas, which is greatly influenced by the Changjiang River (CR, also known as the Yangtze River), the fourth in sediment discharge and the fifth in water discharge in the world (Liu et al., 2006; Wang et al., 2011). In summers, most of the sediments discharged from CR are temporarily stored in the subaerial and subaqueous deltaic systems off the river mouth. But in winters, strong bottom stresses driven by wind-generated waves can re-suspend the deposited sediments (Bian et al., 2013). Meanwhile, the coastal current intensifies in response to arctic outbreaks of cold air masses from northern China and carries the resuspended sediments southward, forming a mud wedge stretching from CR mouth southward to Taiwan strait along the inner shelf of ECS (DeMaster et al., 1985; Huh et al., 2011; Liu et al., 2006; Milliman et al., 1985a; Xu et al., 2009; Yao et al., 2014). Previous studies on clay minerals, heavy metals, organic carbon and grainsize analysis confirmed that CR is the primary source of this mud belt (Dong et al., 2011; Lin et al., 2002; Liu et al., 2006; Xu et al., 2012), and the contribution from local rivers along the coast south of CR is negligible (Chu et al., 2009; Liu et al., 2007).

The properties of sediments are largely mediated by the transport processes that may influence the potential abundance and availability of different size fractions over a range of temporal-spatial scales (Hatfield, 2014). Organic carbon discharged from a river presents either as discrete organic particles or as organic matter closely attached to mineral grains (Bouchez et al., 2014). The former is more prone to degradation because of its higher buoyancy and microbial bioavailability; and the latter is a primary form of organic matter buried in many marine systems (Hedges and Keil, 1995). The reactivity and redistribution of organic matter are greatly influenced by its association with minerals (Blair and Aller, 2012; Goñi et al., 1998; Vonk et al., 2014). Hydrodynamic sorting, which reworks sediment and the associated organic matter depending on the particle size and density, has a critical effect on the behavior of TerOM during the transport process. For example, larger plant debris can be energetically confined to nearshore whereas organic matter attached to fine particles are winnowed and transported much further (Tesi et al., 2008).

The oceanography in ECS, shown in Fig. 1, is dominated by Yellow Sea Coastal Current (YSCC), Changjiang Diluted Water (CDW), ZheMin Coastal Current (ZMCC), Taiwan Warm Current (TWC) and Kuroshio Current (KC). Portions of KC branch out onto the shelf as a result of KC impinging on ECS shelf (Ding et al., 2016; Hsueh, 2000; Zhou et al., 2018). Documented by previous studies, the upper layer of TWC comes mainly from Kuroshio water in winters and the Taiwan strait water contributes significantly in summers, while the lower layer is from Kuroshio subsurface water (Guan and Fang, 2006; Lian et al., 2016; Yuan et al., 2008; Zhou et al., 2015). TWC splits into two branches around $28^{\circ} \mathrm{N}$, the nearshore branch moves northward and can approach as far as $30.5^{\circ} \mathrm{N}$ southeast of CR mouth in summers; while the other turns east, first onto the outer shelf and then turns northeast near the continental slope (Guan and Fang, 2006; Pan, 1987; Yang et al., 2012; Yang et al., 2011; Zhu et al., 2004).

The currents in the eastern ECS are significantly influenced by seasonal variation of East Asia Monsoon (EAM) (Bi et al., 2011). EAM prevails over ECS with a stronger northeast wind in winters and a weaker southwest wind in summers (Guan and Fang, 2006). In the nearshore, ZMCC driven by EAM is strong and flows southward in winters and northeastward in summers (Bian et al., 2013). In the offshore, TWC intensifies in summers in response to the southeast monsoon while ZMCC diminishes (Beardsley et al., 1985; Lee and Chao, 2003).

Seasonal variations of sediment transport in shelf seas, due to seasonally varying ocean currents, are often reported (Castaing et al., 1999; Muslim and Jones, 2003; Yuan et al., 2008). The mixture of the two water masses (ZMCC and TWC) and the intrusion of KC complicate the transport of organic matter in the inner shelf of ECS. Existing studies paid more attention to the effect of ZMCC on the transport of organic matter discharged from CR in winters (Chen, 2009; Li et al., 2016; Wu et al., 2015). These studies overlooked the fact that TWC and the intrusion of KC also play an important role on the dispersal of organic matter in summers since part of the mud belt is in the coverage of TWC. Previous Acoustic Doppler Current Profiler studies in ECS showed that TWC can reach the 30-40 $\mathrm{m}$ isobath in winter (Wu et al., 2013; Zeng et al.,

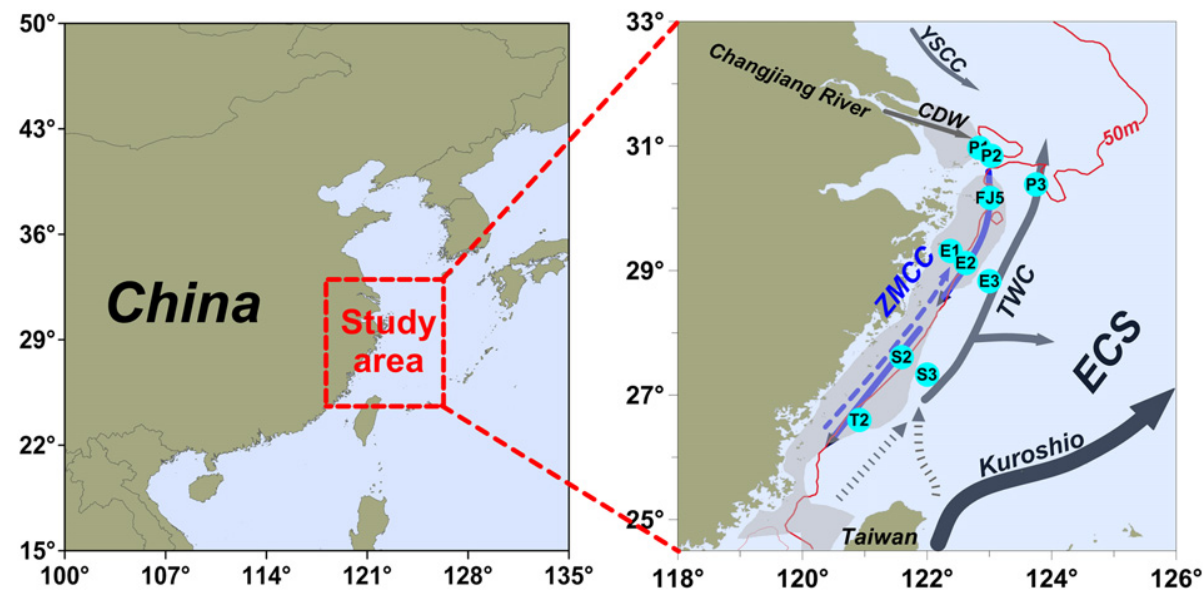

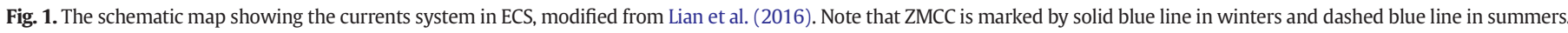

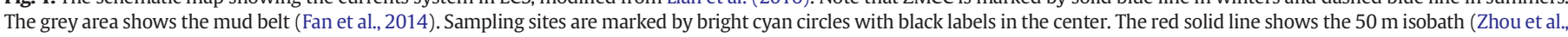
2015). 
2012). Based on the thoroughly studied oceanography and the sediment transport pathways in ECS (Bian et al., 2013; Liu et al., 2006; Yao et al., 2014; Zhou et al., 2018), it is reasonable to sample in the main pathway of sediments in the inner shelf for study on their behaviors during the transport process.

Water elutriation provides simple and efficient access to fractionate samples based on Stokes' Law (Walling and Woodward, 1993). It mimics the "original state" of sediment particles in ocean, which helps to explore the "real" transport and deposition processes. This method has been validated and well documented in a number of previous researches (He et al., 2010; Walling and Woodward, 1993; Zhang et al., 2009). And it has been successfully used in characterizing the transport of organic carbon in Huang River estuary (Zhang et al., 2013a).

Lignin, uniquely synthesized by vascular plants, is an important terrestrial biomarker due to its relatively resistance to degradation and essentially absence from marine derived organic matter (MarOM) (Adler, 1977; Wang et al., 2015). Lignin oxidation products are also indicative of the degradation status of TerOM and of vegetation type (Tesi et al., 2007). Thus, it has been extensively used as a valuable tracer for the transport processes of TerOM and identification of vegetation type in coast and open seas (Hao et al., 2017; Li et al., 2013; Otto and Simpson, 2006; Tesi et al., 2014). As a tracer of TerOM, lignin is assumed to behave the same with TerOM after entering the marine system, including the partitioning among different size fractions and the degradation characteristics.

At the present, the seasonal variation of ZMCC and TWC complicates the hydrodynamic conditions in CR estuary and ECS inner shelf, and its impact on sediment transport has not been fully revealed. The aim of this study was to detail the transport pattern of sediments in ECS inner shelf, a highly dynamic marginal region, using water elutriation combined with lignin, temperature and salinity parameters. The overarching goal is to better understand the effect of hydrodynamic sorting on the fate of TerOM in the ocean. The implication of the study is also discussed.

\section{Materials and methods}

\subsection{Sample collection}

To trace the transport pattern of sediments in ECS inner shelf, 10 sediment samples along the coastline were collected by using a box corer (Qingdao Orson, China) on board of the R/V "Dong Fang Hong 2" during April 2017, and the surface layers $(0-5 \mathrm{~cm})$ were cut using a stainless steel blade. The sites location is shown in Fig. 1 and Table S2. According to a previous study, there are two major sources of sediments in the study area: mud belt area sediments from CR and relict sand area sediments deposited during the late Pleistocene low sea level stands (Zhu et al., 2011b). During the sampling, a Sea-Bird CTD (Sea-Bird911 PLUS, USA) was used to measure the salinity, temperature and depth of seawater at each site.

\subsection{Water elutriation}

The apparatus used in this study is illustrated in Fig. S1. It consists of a glass container, five chambers linked by flexible tubing and a peristaltic pump. Briefly, different chamber diameters provide a sequential reduction in flow velocity. Freshly dispersed sediments are carried by water through chambers from bottom to top. Sediment particles with greater settling velocities than the upward velocities of the flow remain within the chamber, while those with lower settling velocities are carried upwards and into the next chamber (Walling and Woodward, 1993). According to the Stokes' Law, particles with a certain size and density will be settled down in a specific chamber. Each sample was fractionated into five "sizes" of $>63 \mu \mathrm{m}, 32-63 \mu \mathrm{m}, 16-32 \mu \mathrm{m}$, $8-16 \mu \mathrm{m}$ and $<8 \mu \mathrm{m}$

\subsection{Microscopic observation}

The digital microscopic images of each fraction were acquired on a JSM-6700F scanning electron microscope (JEOL Ltd., Japan) at an applied voltage of $8 \mathrm{kV}$. The samples were mounted on an aluminum support using a double-sided adhesive tape and coated with gold in vacuum.

\subsection{Lignin phenol analysis}

Lignin phenols used in this paper include $p$-hyroxybenzenes (P series; including $p$-hyroxybenzoic acid, $p$-hydroxybenzaldehyde and $p$ hydroxyacetophenone), vanillyl phenols ( $V$ series; including vanillic acid, vanillin and acetovanillone), syringyl phenols (S series; including syringic acid, syringaldehyde and acetosyringone), cinnamyl phenols (C series; including $p$-coumaric acid and ferulic acid) and 3,5dihydroxybenzoic acid (Goñi and Hedges, 1995). $\Sigma_{8}(\mu \mathrm{g} / \mathrm{g} \mathrm{dw}$ ), the sum of eight lignin phenols ( $C, S$ and $V$ series) relative to $1 \mathrm{~g}$ dry weight samples, is used as an indicator of TerOM (Hedges et al., 1986). The typical ratios of lignin phenols are shown in Table 1.

The analysis of lignin oxidation phenols were based on the conventional alkaline CuO method (Goñi and Montgomery, 2000) modified by Zhang et al. (2013b). Briefly, about $1 \mathrm{~g}$ freeze-dried and homogenized sediment was added to the reactor together with $100 \mathrm{mg} \mathrm{CuO}$ and $50 \mathrm{mg} \mathrm{Fe}\left(\mathrm{NH}_{4}\right)_{2}\left(\mathrm{SO}_{4}\right)_{2} \cdot 6 \mathrm{H}_{2} \mathrm{O}$. Then, $2 \mathrm{M} \mathrm{NaOH}$ solution was added to the reactor in nitrogen atmosphere. The reactor was capped and placed at $170^{\circ} \mathrm{C}$ for $3 \mathrm{~h}$. After cooling down, the sample solution was spiked with known amounts of ethyl vanillin and trans-cinnamic acid as surrogate standards, and then acidified to a $\mathrm{pH}$ of 1 with concentrated $\mathrm{HCl}$ and extracted by Cleanert SPE column (500 mg, Agela Technologies, China), eluted by ethyl acetate. The eluent was dried under a gentle nitrogen stream and redissolved in acetonitrile. The redissolved sample was derivatized with bis-trimethylsilyl-trifluoro-acetamide plus $1 \%$ trimethylchlorosilane (BSTFA $+1 \%$ TMCS) before injection into the GC system.

An Agilent 6890 series Gas Chromatography coupled with a Flame Ionization Detector was used to analyze lignin oxidation products. Samples were separated by a DB- 1 capillary column $(30 \mathrm{~m} \times 0.25 \mathrm{~mm}$ i. d. $\times 0.25 \mu \mathrm{m}$ film thickness; J\&W Scientific, USA). The temperatures for the detector and injector were set to $300{ }^{\circ} \mathrm{C}$, and the oven temperature began at $100{ }^{\circ} \mathrm{C}$ and ramped at $4{ }^{\circ} \mathrm{C} \mathrm{min}{ }^{-1}$ to $290{ }^{\circ} \mathrm{C}$. The identification of each compound was achieved by comparison of the retention time with those of the standards. Triisopropylbenzene was used as the internal standard to quantify the concentration of each

Table 1

Typical ratios of lignin phenols.

Parameter Description

$\mathrm{C} / \mathrm{V} \quad \mathrm{C}$ phenols are only produced by nonwoody tissues while $\mathrm{V}$ phenols are produced by all vascular plant including woody and nonwoody tissues. The ratio of $C$ phenols to $\mathrm{V}$ phenols is used to differentiate the source of plants. ${ }^{\mathrm{a}}$

LPVI The lignin phenol vegetation index $((S(S+1) /(V+1)+1) \times(C$ $(C+1) /(V+1)+1))$. It is used to differentiate vegetation sources. $^{\text {a }}$

$(\mathrm{Ad} / \mathrm{Al})_{\mathrm{V}} \quad$ The acid to aldehyde ratio of $\mathrm{V}$ phenols which reflects the oxidative degradation of the $\mathrm{V}$ phenols. ${ }^{\mathrm{a}}$

$(\mathrm{Ad} / \mathrm{Al})_{\mathrm{S}} \quad$ The acid to aldehyde ratio of $\mathrm{S}$ phenols which reflects the oxidative degradation of the $\mathrm{S}$ phenols. ${ }^{\text {a }}$

$\mathrm{P} /(\mathrm{V}+\mathrm{S})$ The ratio of $\mathrm{P}$ phenols to the sum of $\mathrm{V}$ and $\mathrm{S}$ phenols which reflects the degradation index of demethylation. ${ }^{\text {b }}$

3,5-Bd/V The ratio of 3,5-dihydroxybenzoic acid to $\mathrm{V}$ phenols which indicates the degree of humification of soil organic matter.

Pon/P The ratio of $p$-hydroxyacetophenone to total $\mathrm{P}$ phenols which reflects the source of P phenols. ${ }^{\mathrm{d}}$

aBianchi et al. (2002), Tareq et al. (2004), Tareq et al. (2006) and Tareq et al. (2011); ${ }^{\mathrm{b} D i t t m a r}$ and Lara (2001); 'Dickens et al. (2007) and Kuzyk et al. (2008); ${ }^{\mathrm{d}}$ Teisserenc et al. (2010). 
compound. The recoveries of surrogates were $107.23 \pm 8.91 \%$ and $91.28 \pm 8.64 \%$ for ethyl vanillin and transcinnamic acid, respectively. The different functional groups between surrogates and target lignin phenols might result in slightly different recoveries. Thus, all data for the lignin phenols were not corrected by the recoveries of surrogates. For randomly selected samples run in duplicate, an overall deviation $<15.24 \%$ for individual phenols was obtained.

\subsection{Total organic carbon (TOC) and total nitrogen (TN)}

The sediments were freeze-dried, homogenized and acidified by reaction with $2 \mathrm{M} \mathrm{HCl}$ for $24 \mathrm{~h}$. Then Milli-Q water was added to rinse the samples to a $\mathrm{pH}$ of 7 . The samples were freeze-dried for further analysis. A Vario MACRO Cube elemental analyzer (Elementar, Germany) was used to quantify the contents of TOC and TN. The deviations of selected samples run in replicate $(n=3)$ for TOC and TN were $0.85 \pm 0.32 \%$ and $0.57 \pm 0.59 \%$, respectively.

\subsection{Statistical analysis}

Linear regression was used to evaluate the relationship between TOC and TN. Since not all of data are in normal distribution, Spearman's rank correlation was used to determine the relationship. All the statistical analysis was performed with IBM SPSS Statistics 22. In addition, Surfer 14 and Origin 2017 softwares were used for graphics.

\section{Results}

\subsection{Microscopic structure for each size fraction}

Representative scanning electron microscope images of each size fraction from site E3 are shown in Fig. 2. Generally, different microscopic structures were observed among different size fractions. Especially, differences are apparent between the coarser fractions (>63 $\mu \mathrm{m}$ and 32-63 $\mu \mathrm{m})$ and the finer fractions (16-32 $\mu \mathrm{m}, 8-16 \mu \mathrm{m}$ and $<8 \mu \mathrm{m})$.
The coarser fractions consist of discrete mineral particles (Fig. 2A and B) while the finer fractions consist of fine-grained particles and loosely bounded aggregates, presumably as organic-mineral complexes (Fig. 2C, D and E).

\subsection{Mass recoveries and distribution of water elutriation fractions}

The total mass recoveries in the water elutriation procedure for each sample varied between $89.38 \%$ and $94.53 \%$, which are similar to those reported in a previous study with a combined fractionation method (Tesi et al., 2016). The mass percentages of fractions at each sampling site are shown in Fig. 3A and Table S2. Generally, the 16-32 $\mu \mathrm{m}$ and 8-16 $\mu \mathrm{m}$ size fractions are dominant at all sites in the mud belt, which are consistent with previous studies that sediments near CR mouth and in ECS inner shelf were mainly silts and clay with a bimodal distribution (Liu et al., 2006; Xu et al., 2009), and are similar to the size distribution of suspended particulates in CR mouth (Milliman et al., 1985b). The sites adjacent to subaqueous delta (P2 and P3) with a high proportion of sandy sediment (corresponding to size $>63 \mu \mathrm{m}$ ) are reflective of the energetic and erosive hydrodynamic conditions that serve to resuspend and transport fine grained sediments southward further, and to expose coarse sand beneath. While on the other hand, there are also relatively higher sandy fractions ( $>63 \mu \mathrm{m})$ at sites E3 and S3, indicative for the relict sand deposited during the late Pleistocene low sea level stands. Relatively high clay $(<16 \mu \mathrm{m})$ contents in the southern sites indicate that finer sediments are being transported farther away from the river mouth. The sites near the coastline (P1, E1, E2, S2 and T2) have lower sandy fractions than the sites far from the coast (P2, P3, E3 and S3).

\subsection{Elemental compositions}

TOC contents of fractionated sediments ranged from $0.15 \%$ to $1.05 \%$ (Table S2). These values are within the range commonly reported for unfractionated samples in ECS (Wang et al., 2015; Ying et al., 2013;

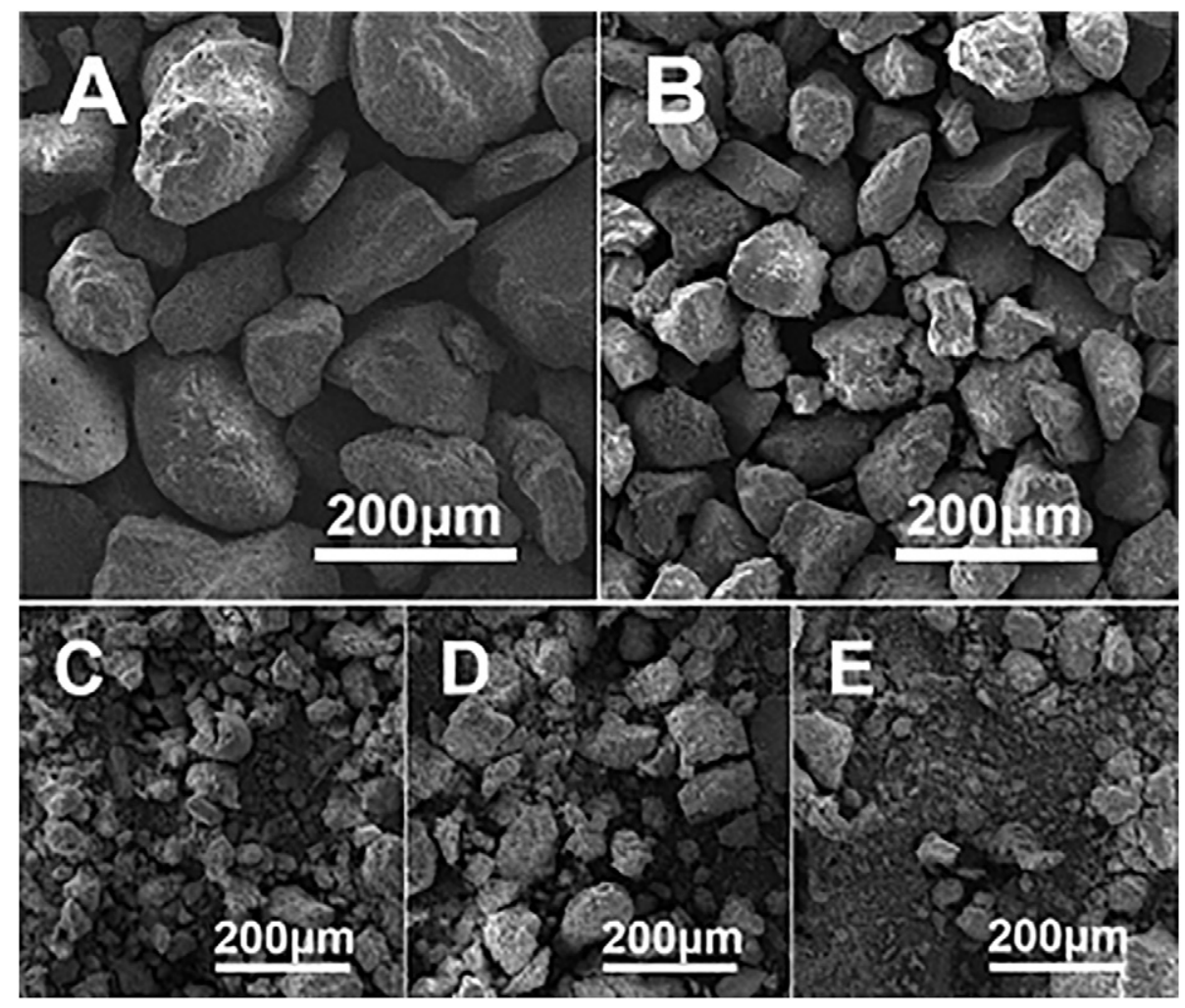

Fig. 2. Scanning electron microscope images of particle morphology for each fraction from site E3. A: $>63 \mu \mathrm{m}$; B: 32-63 $\mu \mathrm{m}$; C: 16-32 $\mu \mathrm{m}$; D: 8-16 $\mu \mathrm{m}$; E: $<8 \mu \mathrm{m}$. 


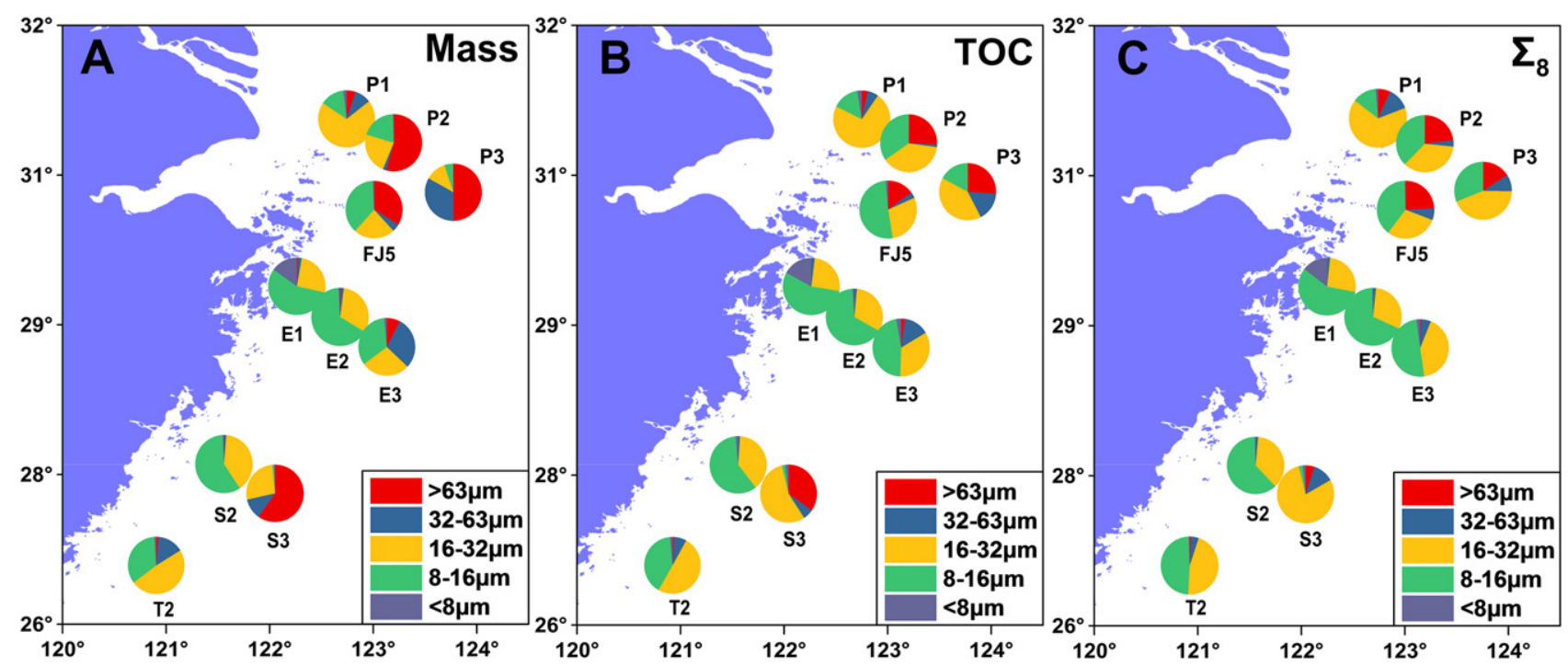

Fig. 3. The percentages of sediment mass (A), TOC (B) and $\Sigma_{8}$ lignin phenols (C) for each fraction at each sampling site.

Zhu et al., 2013). Higher TOC contents are usually observed on the finer size fractions over the coarser ones at the same site (Fig. 4A). The percentages of TOC in 16-32 $\mu \mathrm{m}$ and 8-16 $\mu \mathrm{m}$ fractions dominate all the samples because of their high mass contribution, despite the highest TOC content (normalized to sediment mass) in the finest fraction $(<8 \mu \mathrm{m})$ (Fig. $3 \mathrm{~A}$ and $\mathrm{B})$. The $\mathrm{C} / \mathrm{N}$ ratio is the highest in the coarsest fraction and decreased with decreasing size for all sites except site P3 (Fig. 4B). This trend is consistent with the results of Keil et al. (1998) who used a combination method of SPLITT fractionation and density

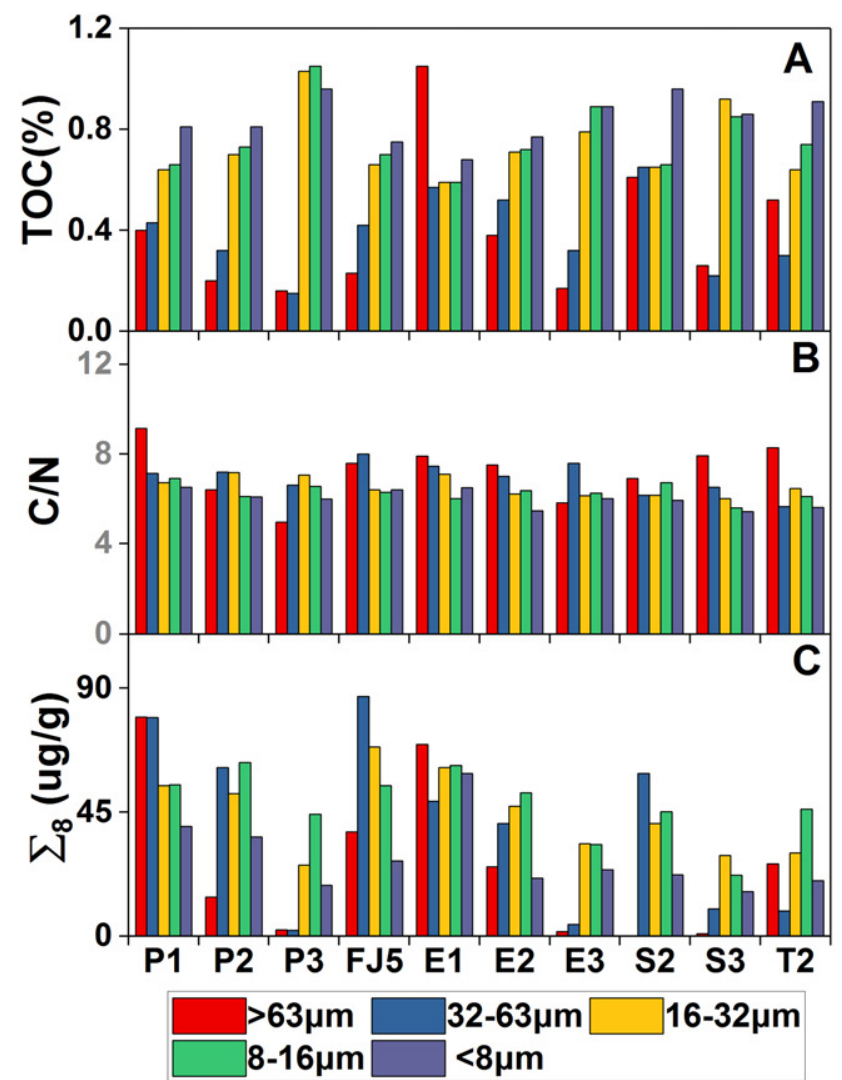

fractionation. Comparing the same fraction at different sites, the ratio generally decreased southward except for the $>63 \mu \mathrm{m}$ fraction (Fig. 4D). Overall, the $\mathrm{C} / \mathrm{N}$ ratio represents an apparent marine signature $(\mathrm{C} / \mathrm{N}$ ratio $<10)$.

\subsection{Lignin phenols}

Detailed results for lignin phenols are shown in Table S3. The $\Sigma_{8}$ lignin phenols ranged from 0.83 to $86.95 \mu \mathrm{g} / \mathrm{g} d \mathrm{w}$ with an average value of

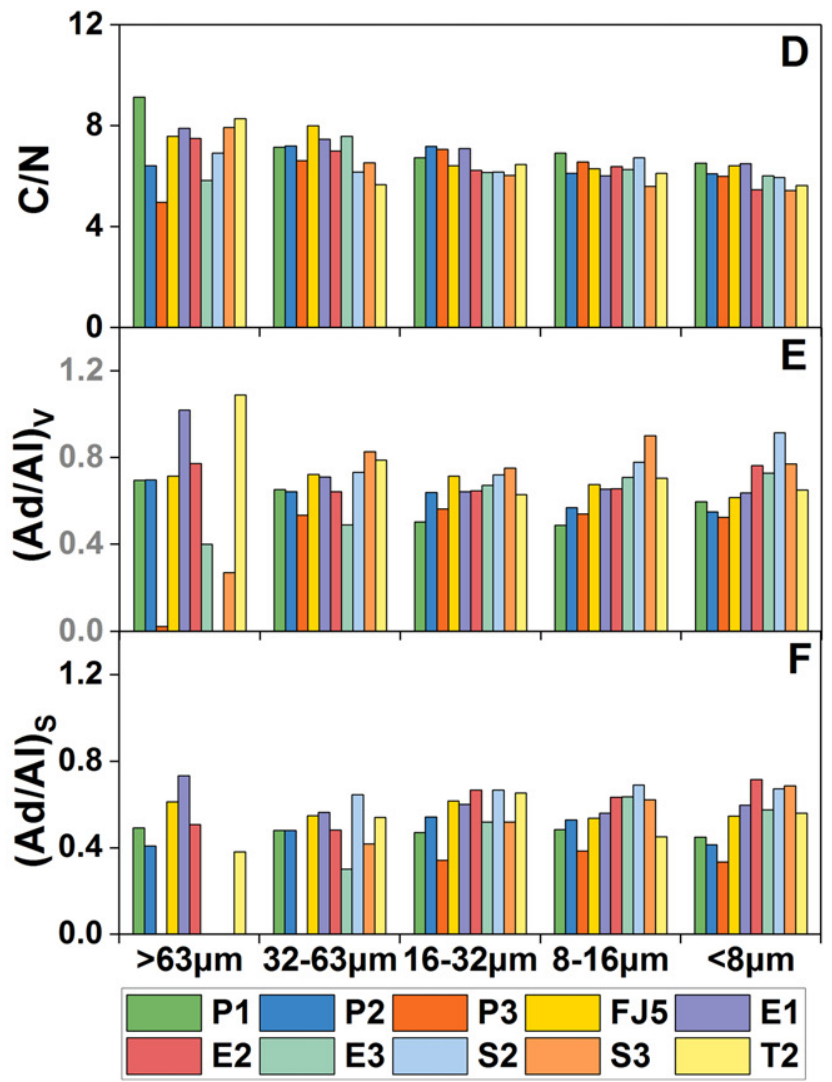

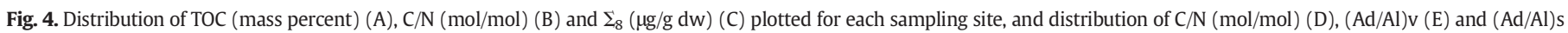
(F) plotted for each fraction. Note that some fraction was not detected or unavailable because of insufficient sample quantity. 
$38.03 \pm 22.40 \mu \mathrm{g} / \mathrm{g} \mathrm{dw}$, which are consistent with previous studies of unfractionated samples (Li et al., 2012). Most of the $\Sigma_{8}$ lignin phenols are concentrated in the medium-grained fractions (Fig. 3C). Previous studies on river-dominated marginal seas showed that the vascular plant debris is mostly retained in shallow waters as it behaves hydraulically as sandy or silty material (Bianchi et al., 2002; Wakeham et al., 2009). Site P1 is adjacent to CR estuary and the high value of $\Sigma_{8}$ lignin phenols in $>63 \mu \mathrm{m}$ size fraction at site P1 comes mostly from distinct vascular plant debris (Fig. 4C). Note that lignin parameters for the $>63 \mu \mathrm{m}$ fraction at site S2 were not determined because of insufficient sample quantity.

The $(\mathrm{Ad} / \mathrm{Al})_{\mathrm{V}}$ and $(\mathrm{Ad} / \mathrm{Al})_{\mathrm{S}}$ ranged from 0.02 to 1.09 and from 0.30 to 0.73 , with average values of $0.66 \pm 0.17$ and $0.53 \pm 0.10$, respectively, suggesting a relatively higher degradation degree of lignin in ECS inner shelf. Both of them increased at first while sampling site moving southward, and then decreased for the 32-63 $\mu \mathrm{m}, 16-32 \mu \mathrm{m}, 8-16 \mu \mathrm{m}$ and $<8 \mu \mathrm{m}$ fractions (Fig. $4 \mathrm{E}$ and F) with a few exceptions (sites P3, E3 and S3).

\section{Discussion}

\subsection{Implication of different parameters}

The $\mathrm{C} / \mathrm{N}$ ratio has been traditionally used to distinguish TerOM from MarOM. A significant linear relationship between TN and TOC with a negative intercept $\left(R^{2}=0.94, p<0.01\right.$, Fig. $\left.5 A\right)$ suggests that TN is derived predominantly from organic origin (Li et al., 2014a). It has been found that the nonconservative behavior of $\mathrm{C} / \mathrm{N}$ ratio is mainly caused by sorption of nitrogenous materials to minerals and/or microbial activity (Keil et al., 1998; Tesi et al., 2007; Yao et al., 2015). C/N ratio for the same fraction progressively decreases southward (except for $>63 \mu \mathrm{m}$ fraction) (Fig. 4D) until below the Redfield ratio (typically 6.6 for MarOM), suggesting that the progressively loss of TerOM couples with presence of bacterial biomass (Ruttenberg and Goñi, 1997; Tesi et al., 2007) and replacement of TerOM by MarOM as sediment transported southward along the inner shelf. Nitrogenous organic materials are preferentially removed during diagenesis (Dai et al., 2005) and are more readily recycled than the bulk carbon during sedimentation and burial processes (Stevenson and Cheng, 1972). Therefore, the degradation of organic carbon alone could not be the reason for the decreased C/N ratio. Surface sediments in ECS inner shelf are mainly composed of silt and clay as shown in the mass distribution (Fig. 3A and Table S2 in this study), and dominated by illite according to previous mineralogical analysis (Liu et al., 2006; Xu et al., 2009). These silts and clays with both large surface area and negatively charged surface are capable of adsorbing ammonia (Ogrinc et al., 2005; Ruttenberg and Goñi, 1997). The result that $\mathrm{C} / \mathrm{N}$ ratio decreases with decreasing particle size for the same site (Fig. 4B) implies the possible increased bacteria biomass and sorption of nitrogenous organic matter (including MarOM) to minerals with decreasing size.

Previous studies have also shown that nonwoody soft tissues are usually associated with fine-grained sediments, and are transported
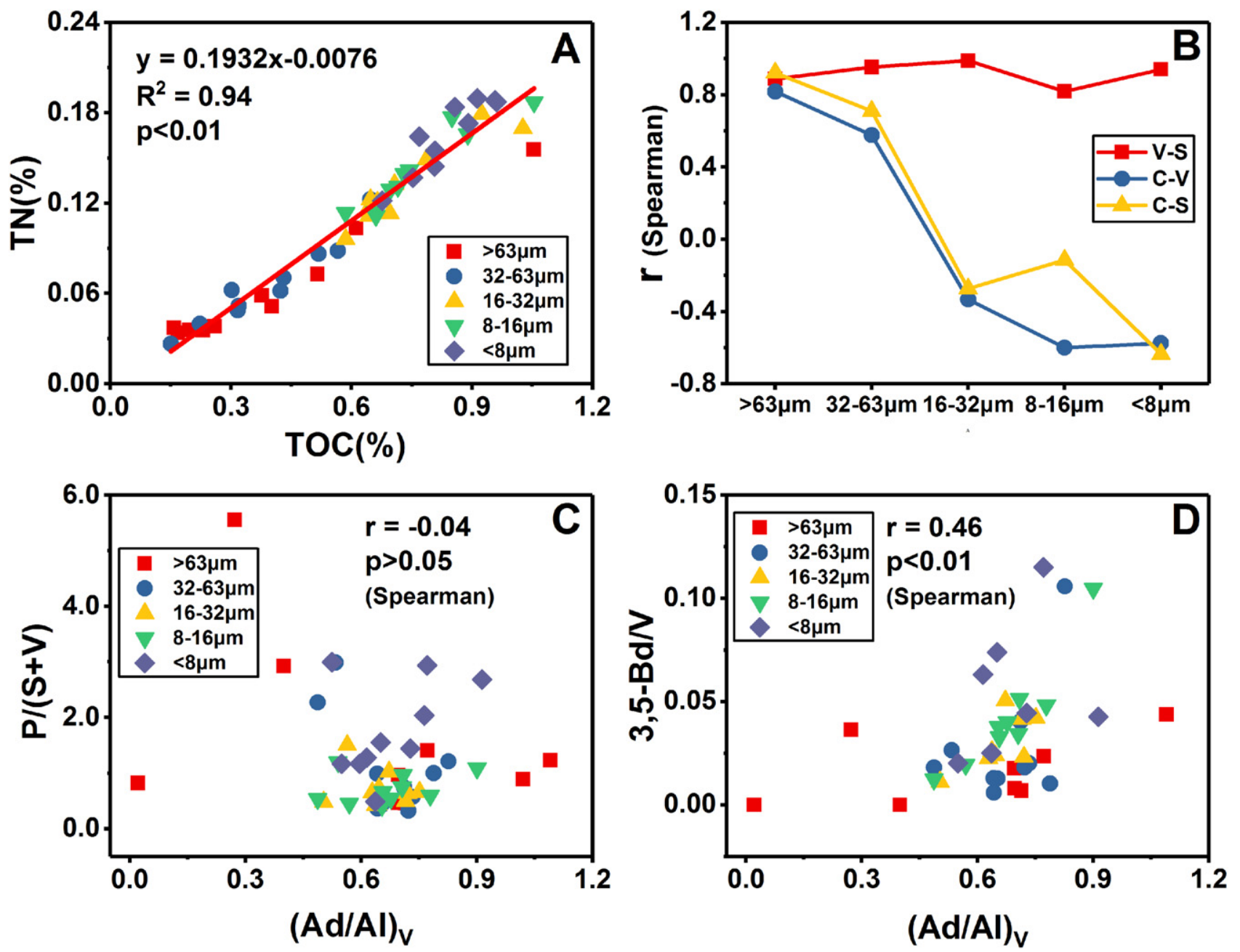

Fig. 5. Relationship of TN versus TOC $(A), P /(S+V)$ versus $(\mathrm{Ad} / \mathrm{Al})_{\mathrm{V}}(\mathrm{C}), 3,5-\mathrm{Bd} / \mathrm{V}$ versus $(\mathrm{Ad} / \mathrm{Al})_{\mathrm{V}}(\mathrm{D})$ and Spearman correlation coefficients between the three lignin phenols $(\mathrm{B})$. 
further offshore under hydrodynamic forcing; whereas the hard woody materials are usually associated with coarser particles, deposited closer to the river mouth (Bianchi et al., 2002; Bianchi et al., 2011; Goñi et al., 1998; Hu et al., 2012). Fig. 5B clearly shows the Spearman correlation coefficients between the three lignin phenols. $S$ phenols are well correlated with $\mathrm{V}$ phenols in all size fractions, while the correlation of $\mathrm{C}$ phenols with both $\mathrm{S}$ and $\mathrm{V}$ phenols decreases with decreasing sediment particle size. The partitioning of $C$ phenols among different size fractions is not in synchronization with $\mathrm{S}$ and $\mathrm{V}$ phenols. There are two possibilities for this phenomenon: (i) The diagenetic reactivity of $C$ phenols is higher than those of S and V phenols (Huang et al., 1999; Opsahl and Benner, 1995; Tareq et al., 2004); (ii) the relative enrichment of $C$ phenols in finer fractions (Fig. S2). That is to say, nonwoody tissues are more easily associated with finer sediments, as discussed above. Since the finer grained minerals have enhanced preservation of TerOM, the nonwoody tissues in finer fractions can be strongly attached to mineral surfaces and preserved better by wedging into micropores, or "armoring" in microfabric between sediment particles; while the coarser fractions are depleted of nonwoody tissues, or more susceptible to degradation.

The hydrodynamic sorting process separates fine grained sediments from coarse grained ones. This may result in underestimating the contribution of nonwoody plants in coarse grained sediments or overestimating the contribution of nonwoody plants in fine grained sediments. Therefore, it is believed that distribution of $C$ phenols reflects the collective effects of diagenetic reactivity, association preference with finer sediments and hydrodynamic sorting, rather than a single process. Notably, this hampers the use of $C$ phenols and related parameters (C/V and LPVI) in identifying the vegetation in fractionated sediments. A study in Washington Coast showed that the off-shore sites have enhanced nonwoody input or preservation, which indicated distinct sorting of terrestrial biochemicals (Keil et al., 1998). In conclusion, the effect of hydrodynamic sorting should be considered when using lignin vegetation parameters.

$\mathrm{P} /(\mathrm{S}+\mathrm{V})$ was used to indicate the demethylation degradation of lignin. If $\mathrm{P}$ phenols is exclusively derived from vascular plants, a significant correlation should be observed between $\mathrm{P} /(\mathrm{S}+\mathrm{V})$ and $(\mathrm{Ad} / \mathrm{Al})_{\mathrm{V}}$. As indicated by a lack of correlation between $\mathrm{P} /(\mathrm{S}+\mathrm{V})$ and $(\mathrm{Ad} / \mathrm{Al})_{\mathrm{V}}(r=$ $-0.04, p>0.05$, Fig. 5C), a large part of the P phenols is not derived from terrestrial vascular plant. An average value of Pon $/ P<0.10$ further confirmed this point since Pon ( $p$-hydroxyacetophenone) is generally considered as a product exclusively derived from lignin. The correlation between 3,5-Bd/V and C/V is strong ( $r=0.78, p<0.01$, Spearman), implying that $3,5-B d$ is also influenced by hydrodynamic sorting, as the same as $C$ phenols. A previous study on the effect of hydrodynamic sorting on lignin compositional variation in Hudson Bay found that $3,5-\mathrm{Bd} / \mathrm{V}$ increased from inner shelf to outer shelf, which was corresponded to increased C/V ratios (Kuzyk et al., 2008). The correlation of 3,5-Bd/V with $(\mathrm{Ad} / \mathrm{Al})_{\mathrm{V}}$ is weak $(r=0.46, \mathrm{p}<0.01$, Fig. 5D). This is not only because of the hydrodynamic sorting effect, but also the addition of marine sources, since 3,5-Bd can also be released from marine kelps and brown macroalgae (Farella et al., 2001; Stephane et al., 2006). Overall, the $3,5-\mathrm{Bd} / \mathrm{V}$ is not an accurate parameter to trace the diagenetic status and transport pathway of sediments, neither is the $\mathrm{P} /(\mathrm{S}+\mathrm{V})$.

\subsection{The along shelf transport of TerOM}

According to the disperse pathway induced from the currents in ECS inner shelf, six sites (P1, P2, FJ5, E2, S2 and T2) were selected to trace the transport of TerOM.

Previous works have shown that frequent resuspension of materials in mobile muds belts would enhance degradation of organic carbon (Blair and Aller, 2012; Keil et al., 1997). The use of Ad/Al parameters to trace the transport of TerOM is based on this assumption that the more circling of resuspension and redeposition of the sediments experienced, the more oxidative degradation occurred. Illustrated by $(\mathrm{Ad} / \mathrm{Al})_{\mathrm{V}}$ ratios, Fig. $6 \mathrm{~A}$ shows the degradation status of TerOM southward from $\mathrm{CR}$ mouth to the Fujian inner shelf. The $(\mathrm{Ad} / \mathrm{Al})_{\mathrm{V}}$ ratios increased southward for both the two coarser fractions ( $>63 \mu \mathrm{m}$ and 32-63 $\mu \mathrm{m})$. But for the finer fractions (16-32 $\mu \mathrm{m}, 8-16 \mu \mathrm{m}$ and $<8 \mu \mathrm{m})$, the ratio increased to the maximum at site S2 and then decreased (Fig. 6A). The $(\mathrm{Ad} / \mathrm{Al})_{S}$ shows a similar trend with a subtle difference (Fig. 6B), which is caused by the higher diagenetic reactivity of S phenols (Louchouarn et al., 1997; Opsahl and Benner, 1995). The southernmost site is the farthest from the river mouth. Therefore, sediment in the southernmost is believed to have the highest value of $\mathrm{Ad} / \mathrm{Al}$ since they have undergone the longest degradation time. This is true for $(\mathrm{Ad} / \mathrm{Al})_{\mathrm{V}}$ ratios of the coarser fractions (both the two fractions $>32 \mu \mathrm{m}$ ). But for both $(\mathrm{Ad} / \mathrm{Al})_{\mathrm{V}}$ and $(\mathrm{Ad} / \mathrm{Al})_{\mathrm{S}}$ of the finer fractions (all the three fractions $<32 \mu \mathrm{m}$ ), the diagenetic state of TerOM at site S2 is higher than that at site T2 in the south (note that in some fractions, the highest diagenetic state was observed at site E2, to the north of T2 and S2). This phenomenon is ascribed to the seasonal variation of ZMCC, TWC and intrusion of KC. It seems like that TerOM associated with finer mineral particles are more easily resuspended and carried farther southward by the strong ZMCC in winters; but in summers, they are carried backward to some extent by the intensified TWC and the intrusion of KC. The finer the sediments are, the more susceptible to this process. Therefore, the finer sediments at site S2 (or E2) experienced further degradation than those at the southern ones and displayed highest value of $\mathrm{Ad} /$ Al.

If this is true, other parameters should also display the similar patterns. Lignin in the sediment at the southernmost site is expected to lose the most because of the longest degradation time. For the same reason, the finest fraction transported the farthest along its pathway; sediment at the southernmost site is then believed to have the highest mass percentage for the finest fraction. With the implication of hydrodynamic sorting on the $C$ lignin phenols discussed above, $\Sigma_{6}(\mu \mathrm{g} / \mathrm{g} \mathrm{dw}$ ) (the sum of six lignin phenols relative to $1 \mathrm{~g}$ dry weight samples, excluding $C$ phenols because of its association with the finer sediments) (Table 1) was used to trace the transport of sediments. However, the results showed that the $\Sigma_{6}$ decreased southward to the lowest at sites S2 and E2 for 8-16 $\mu \mathrm{m}$ and $<8 \mu \mathrm{m}$ fractions, respectively, and then increased (Fig. 6C), in consistence with the degradation parameters. This demonstrates that the finer sediments at sites S2 and E2 have undergone more degradation, and thus have lower lignin contents than at the southern ones. Besides, the mass distribution of size fraction 8-16 $\mu \mathrm{m}$ firstly increases southward to the highest at site E2 and then decreases (Fig. 6D). This distribution pattern further confirmed the above conclusion that some of the finer sediments moved back to the northern sites, also drawn from degradation parameters and $\Sigma_{6}$.

A modeling study using Princeton Ocean Model showed that once the local wind stress was removed from the model, the flows along Chinese mainland coast disappeared (Ma et al., 2010), suggesting that ZMCC is mainly manipulated by EAM and changes direction seasonally. Some researchers also argue that both ZMCC and TWC have seasonal variations in terms of direction and magnitude, and ZMCC changes its direction following the reversing of monsoon to northeast in winters and to southwest in summers (Huang et al., 2016; Su, 2001). A kinematic study using Regional Ocean Modeling System on a transect showed that ECS coastal current in the west flows southward and encounters the northward TWC at the depth of about $40 \mathrm{~m}$ in winters and the whole transect shows a northward flows velocity in summers (Gan et al., 2016). Another study using Regional Ocean Modeling System indicated that most of the sediments transported southward in winters to the mud belt area off the Zhe-Min coast is transported backward by the northward current in summers (Bian et al., 2013).

In summers, the coverage of TWC is expanded because of the intensified northward EAM; and ZMCC is suppressed to the westernmost coast or even merges with TWC and flows northeastward (Bian et al., 2013; Zeng et al., 2012). 



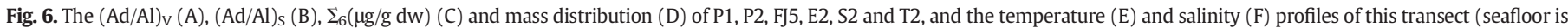
shown in white) in spring.

Temperature and salinity are good tracers to identify different water masses. It is clear that the upper layer is mainly dominated by cold and brakish ZMCC, and a warm and saline tongue expanded from south to site E2 in the lower layer (Fig. 6E and F). The warm and saline tongue is attributed to the northward intrusion of KC. The intrusion of KC may carry the easily resuspended finer sediments northward. Field observation of salinity profile in this area also suggested the northward intrusion of KC at bottom layers lower than $50 \mathrm{~m}$ isobath in ECS inner shelf (Yang et al., 2011); and site S2 is in the coverage of the intrusion pathway. The temperature and salinity profiles provide additional evidence to support the initial northward transport hypothesis of sediments in summers and to interpret the observed mass distribution pattern and lignin parameters.

Overall, a large amount of sediments discharged from $C R$ is transported to the mud belt by the southward ZMCC in winters, providing a supply of fine grained sediments. Then, from springs to summers, the southward EAM attenuates and turns to the northward, gradually promoting the shrinking of ZMCC and even the changing of its direction to the north. The northward TWC and the intrusion of KC transport the fine grained sediments northward to some extent. These results were in consistence with the sediments transportation research in ECS inner shelf in summer (Chen et al., 2017), and supported by sediment transport patterns noted in previous ocean modeling studies.

\subsection{The cross-shelf transport of TerOM}

In winters, the surface ZMCC is driven southward by the strong EAM. Under the Coriolis Effect, a downwelling regime is formed near the coast by the inshore transport in the surface layer and offshore transport in the bottom (Cookman and Flemings, 2001). In addition, TWC causes upwelling offshore. The nearshore downwelling and offshore upwelling have blocked the cross-shelf transport of sediments as many studies indicated (Guo et al., 2002; Li et al., 2014a; Lin et al., 2013; Xu et al., 2012; Yuan et al., 2008). A field study combining with numerical modeling on suspended particulate matters showed that the bottom Ekman transport driven by northerly wind is the key factor controlling the crossfront transport and it expands with intensified northerly wind (Liu et al., 2015). After crossing the front, the sediments could be transported to the outer shelf by the offshoots of TWC (Guan and Fang, 2006). In summers, Monsoon winds turn southwest and the surface ZMCC becomes weak or even merges with TWC, transporting suspended particulates northward as discussed above. Accordingly, the front between ZMCC and TWC is very weak or disappears (Chen, 2009). A previous study showed that during downwelling-favorable monsoon seasons, the ambient pycnocline descends sharply in the down shelf direction; and then the offshore transport of coastal water occurs due to the JEBAR (joint effect of baroclinicity and relief) (Wu, 2015). A study in ECS showed that suspended sediments spread farther to the open sea in winters than in summers (Wang and Jiang, 2008). This is the impact of relative strength of ZMCC and TWC on the cross-shelf transport. Overall, the circulations control the cross-shelf transport of sediments along the Zhe-Min coast in ECS (Qiao et al., 2017).

Three small transects (P1-P2-P3, E1-E2-E3 and S2-S3) were selected to trace the possible cross-shelf transport pattern. It is expected that the $\mathrm{Ad} / \mathrm{Al}$ of sediments increased in amplitude with increasing distance off shore. However, most of the $(\mathrm{Ad} / \mathrm{Al})_{\mathrm{V}}$ (Fig. $7 \mathrm{~A}$ and $\left.\mathrm{B}\right)$ and $(\mathrm{Ad} / \mathrm{Al})_{\mathrm{S}}$ (Fig. 7D, E and F) for sites farther off the shoreline (P3, E3 and S3) are lower than those for mud belt sites (closer to the shoreline) for the same size fractions, demonstrating that sediments do not simply spread laterally. Moreover, an opposite trend between $(\mathrm{Ad} / \mathrm{Al})_{\mathrm{V}}$ and $(\mathrm{Ad} / \mathrm{Al})_{\mathrm{S}}$ in 

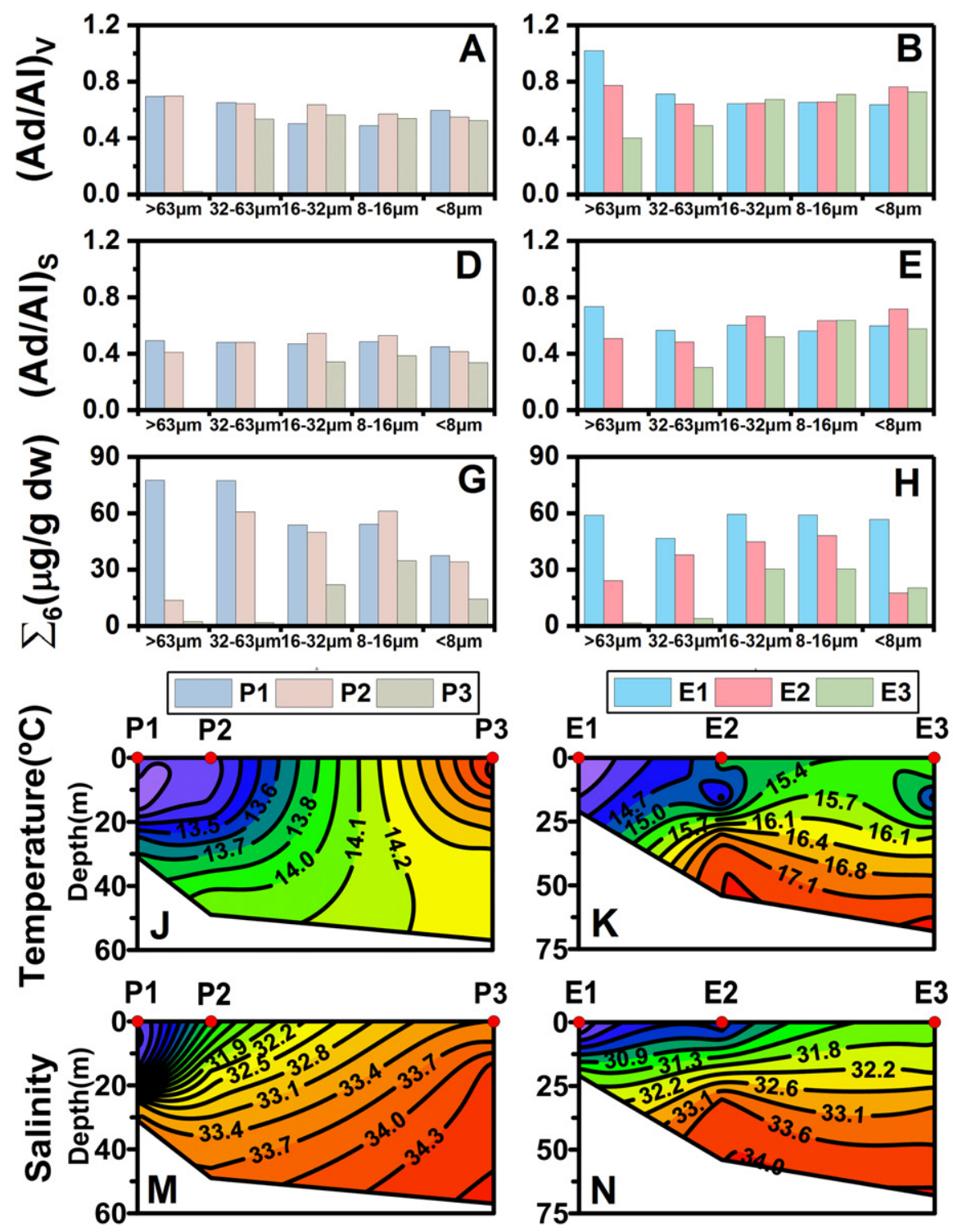
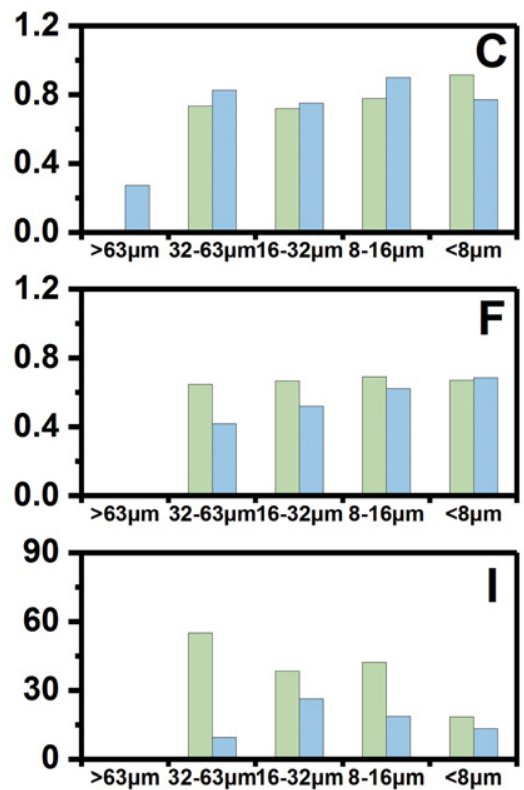

S2 $\square$ S3
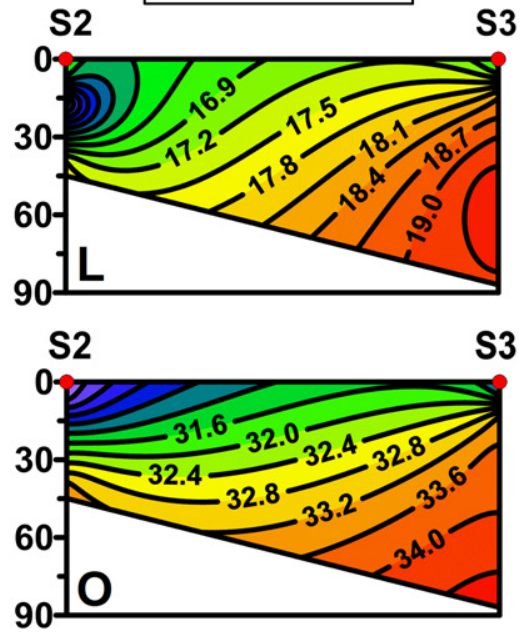

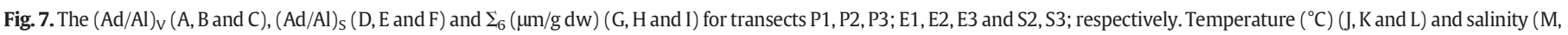
$\mathrm{N}$ and $\mathrm{O}$ ) profiles of the three transects are also shown at the bottom portion.

8-16 $\mu \mathrm{m}, 16-32 \mu \mathrm{m}$ and 32-64 $\mu \mathrm{m}$ size fractions at sites S2 and S3 was observed (Fig. 7C and F), implying the complex cross-shelf transport at the southern sites. It seems that the Ad/Al ratios failed to trace the crossshelf transport of sediments. Nonetheless, it reveals the complicated hydrodynamics that was well documented in the study area (Bi et al., 2017; Li et al., 2014b; Qiao et al., 2006). As expected, the $\Sigma_{6}(\mu \mathrm{g} / \mathrm{g} \mathrm{dw}$ ) generally showed a decreasing trend with increasing distance off shore (except for $8-16 \mu \mathrm{m}$ size fraction at site $\mathrm{P} 2$ and $<8 \mu \mathrm{m}$ size fraction at site E3) (Fig. 7G, H and I). As a whole, the seaward-transported organic matter have experienced long-time multiple episodes of transport, resuspension and redeposition in various transport directions before settled down at the relict sand area where they are finally buried farther from the shoreline. The seasonal variations of ZMCC and TWC further complicate the hydrodynamics and introduce uncertainties caused by mixing of sediments from different sources, especially for the southern sites.

Temperature and salinity profiles clearly show the different water masses in the three transects. The densest isotherms and isohalines generally indicate the front between ZMCC and TWC, which is tilted seaward and upward. Section P1-P2-P3 is influenced by the warm and fresh Changjiang Diluted Water and the cold and saline TWC (Fig. 7J and $\mathrm{M}$ ). The inshore water-mixing is stronger than that offshore. The temperature and salinity are low near shore and in shallow water; and both of them increase seaward. Previous studies on sediment transport in transects from CR mouth to Okinawa Trough showed that crossshelf bottom flows were evident, which were believed to be produced by winter monsoons (Peng and Hu, 1997; Yanagi et al., 1996).

The inshore water of section E1-E2-E3 is controlled by ZMCC, while the offshore water is dominated by TWC and the intrusion of KC. The KC branch intrudes the shelf to about $40 \mathrm{~m}$ isobaths and overlays by TWC surface water with lower temperature and salinity. Explicitly, there is a warm and saline tongue intruded to about $40 \mathrm{~m}$ isobaths shoreward, and upwelled to about $25 \mathrm{~m}$ water depth (Fig. 7K and $\mathrm{N}$ ). The tongue comes mainly from KC climbing water. Under unstable stratified boundary flows, upwelling provides more turbulent energy for sediment suspension (Wu et al., 2015). And buoyant coastal waters usually propagate along the coast, and transport terrestrial matters into the inner shelf and then into open ocean (Wu et al., 2013). TerOM attached to the particles can be resuspended and be carried seaward by the buoyant ZMCC above TWC. Numerical tracer experiments also showed that 
the transition of monsoon from northeasterly to southwesterly in spring favors the transport of coastal water eastward or northeastward, which drives the cross-shelf transport in this area (Ren et al., 2015).

It is also easy to distinguish ZMCC from TWC in transect S2-S3 (Fig. 7L and 0 ). ZMCC is characterized by low temperature and salinity near shore and in shallow water, while TWC is identified with high temperature and salinity off shore and in deep water. Given the overall temperature profiles of the three transect (Fig. 7J, K and L), TWC attenuates as it moves northward and weakens the influence of ZMCC in the south. As a result, the cross-shelf transport is more complicated in this section since ZMCC is more susceptible to the interaction with TWC, introduced by EAM in the southern Zhe-Min coast.

\section{Conclusions}

During the process of southward transport, the sediments discharged from CR are extensively partitioned and degraded, which is reflected by size-dependent mass distribution and $\mathrm{Ad} / \mathrm{Al}$ ratios. The $\mathrm{C} /$ $\mathrm{N}$ ratio of the same fraction shows a southward-decreasing trend, suggesting the progressively degradation of TerOM couples with presence of bacterial biomass and replacement of TerOM by MarOM. The $\mathrm{C}$ lignin phenols are preferentially concentrated in the finer fractions, which might be the collective effect of hydrodynamic sorting, diagenetic reactivity and association preference of $C$ phenols with finer sediments. This phenomenon should be considered when using the $C$ phenol parameters to identify the vegetation sources. Without the perspective afforded by water elutriation, different partitioning behaviors of these geochemical components among different size fractions, resulting largely from hydrodynamic sorting, could be easily misinterpreted.

Under the influence of EAM, an active deposition system in ECS inner shelf was observed as a result of interaction between ZMCC and TWC. The sediments are transported along shelf southward by the strong ZMCC in winters and carried back to some extent in summers, due to the attenuation of southward ZMCC, the intensification of TWC and the intrusion of KC. EAM-induced variation of currents plays a key role on the cross-shelf transport of sediments.

These results provide a new transport pattern of sediments in ECS, which greatly improve the understanding on organic carbon burial in marginal seas and carbon cycle in the ocean. It is therefore an important requirement for predicting the fate of TerOM, modeling ocean carbon cycle and consequently for predicting the near future climate change.

\section{Declaration of competing interests}

The authors declare that they have no known competing financial interests or personal relationships that could have appeared to influence the work reported in this paper.

\section{Acknowledgements}

This work was financially supported by the National Natural Science Foundation of China [NSFC Grant nos. 41276067 and 41020164005] and the National Basic Research Program of China (973 Program). We sincerely express our thanks to the crew members of R/V Dong Fang Hong 2 and the team of the National Key Research and Development Program (No. 2016YFA0601300) for invaluable help in the field.

\section{Appendix A. Supplementary data}

Supplementary data to this article can be found online at https://doi. org/10.1016/j.scitotenv.2019.135699.

\section{References}

Adler, E., 1977. Lignin chemistry-past, present and future. Wood Sci. Technol. 11, 169-218.
Beardsley, R.C., Limeburner, R., Yu, H., Cannon, G.A., 1985. Discharge of the Changjiang (Yangtze River) into the East China Sea. Cont. Shelf Res. 4, 57-76.

Bi, N., Yang, Z., Wang, H., Fan, D., Sun, X., Lei, K., 2011. Seasonal variation of suspendedsediment transport through the southern Bohai Strait. Estuar. Coast. Shelf Sci. 93, 239-247.

Bi, L., Yang, S., Zhao, Y., Wang, Z., Dou, Y., Li, C., et al., 2017. Provenance study of the Holocene sediments in the Changjiang (Yangtze River) estuary and inner shelf of the East China sea. Quat. Int. 441, 147-161.

Bian, C., Jiang, W., Greatbatch, R.J., 2013. An exploratory model study of sediment transport sources and deposits in the Bohai Sea, Yellow Sea, and East China Sea. J. Geophys. Res. Oceans. 118, 5908-5923.

Bianchi, T.S., Mitra, S., McKee, B.A., 2002. Sources of terrestrially-derived organic carbon in lower Mississippi River and Louisiana shelf sediments: implications for differential sedimentation and transport at the coastal margin. Mar. Chem. 77, 211-223.

Bianchi, T.S., Wysocki, L.A., Schreiner, K.M., Filley, T.R., Corbett, D.R., Kolker, A.S., 2011 Sources of terrestrial organic carbon in the Mississippi Plume Region: evidence for the importance of coastal marsh inputs. Aquat. Geochem. 17, 431-456.

Blair, N.E., Aller, R.C., 2012. The fate of terrestrial organic carbon in the marine environment. Annu. Rev. Mar. Sci. 4, 401-423.

Bouchez, J., Galy, V., Hilton, R.G., Gaillardet, J., Moreira-Turcq, P., Pérez, M.A., et al., 2014 Source, transport and fluxes of Amazon River particulate organic carbon: insights from river sediment depth-profiles. Geochim. Cosmochim. Acta 133, 280-298.

Castaing, P., Froidefond, J.M., Lazure, P., Weber, O., Prud'homme, R., Jouanneau, J.M., 1999. Relationship between hydrology and seasonal distribution of suspended sediments on the continental shelf of the Bay of Biscay. Deep-Sea Res. Part II-Top. Stud. Oceanogr. 46, 1979-2001.

Chen, C.-T.A., 2009. Chemical and physical fronts in the Bohai, Yellow and East China seas J. Mar. Syst. 78, 394-410.

Chen, B., Gao, F., Liu, j., 2017. Sediment transport mechanism in the Zhejiang inner continental shelf in summer. Acta Oceanol. Sin. (Chin. Ed.)/Haiyang Xuebao. 39, 96-105.

Chu, Z.X., Zhai, S.K., Lu, X.X., Liu, J.P., Xu, J.X., Xu, K.H., 2009. A quantitative assessment of human impacts on decrease in sediment flux from major Chinese rivers entering the western Pacific Ocean. Geophys. Res. Lett. 36, L19603.

Cookman, J.L., Flemings, P.B., 2001. STORMSED1.0: hydrodynamics and sediment transport in a 2-D, steady-state, wind- and wave-driven coastal circulation model. Comput. Geosci. 27, 647-674.

Dai, J., Sun, M.-Y., Culp, R.A., Noakes, J.E., 2005. Changes in chemical and isotopic signatures of plant materials during degradation: implication for assessing various organic inputs in estuarine systems. Geophys. Res. Lett. 32.

DeMaster, D.J., McKee, B.A., Nittrouer, C.A., Jiangchu, Q., Guodong, C., 1985. Rates of sediment accumulation and particle reworking based on radiochemical measurements from continental shelf deposits in the East China Sea. Cont. Shelf Res. 4, 143-158.

Dickens, A.F., Gudeman, J.A., Gélinas, Y., Baldock, J.A., Tinner, W., Hu, F.S., et al., 2007. Sources and distribution of CuO-derived benzene carboxylic acids in soils and sediments. Org. Geochem. 38, 1256-1276.

Ding, R., Huang, D., Xuan, J., Mayer, B., Zhou, F., Pohlmann, T., 2016. Cross-shelf water exchange in the East China Sea as estimated by satellite altimetry and in situ hydrographic measurement. J. Geophys. Res. Oceans. 121, 7192-7211.

Dittmar, T., Lara, R.J., 2001. Molecular evidence for lignin degradation in sulfate-reducing mangrove sediments (Amazônia, Brazil). Geochim. Cosmochim. Acta 65, 1417-1428.

Dong, L.X., Guan, W.B., Chen, Q., Li, X.H., Liu, X.H., Zeng, X.M., 2011. Sediment transport in the Yellow Sea and East China Sea. Estuar. Coast. Shelf Sci. 93, 248-258.

Fan, Y., Lan, J., Li, H., Cao, Y., Zhao, Z., Wang, J., et al., 2014. Use of lipid biomarkers for identification of regional sources and dechlorination characteristics of polychlorinated biphenyls in the East China Sea. Sci. Total Environ. 490, 766-775.

Farella, N., Lucotte, M., Louchouarn, P., Roulet, M., 2001. Deforestation modifying terrestrial organic transport in the Rio Tapajós, Brazilian Amazon. Org. Geochem. 32, 1443-1458.

Gan, J., Liu, Z., Liang, L., 2016. Numerical modeling of intrinsically and extrinsically forced seasonal circulation in the China seas: a kinematic study. J. Geophys. Res. Oceans. 121, 4697-4715.

Goñi, M.A., Hedges, J.I., 1995. Sources and reactivities of marine-derived organic matter in coastal sediments as determined by alkaline $\mathrm{CuO}$ oxidation. Geochim. Cosmochim. Acta 59, 2965-2981.

Goñi, M.A., Montgomery, S., 2000. Alkaline CuO oxidation with a microwave digestion system:lignin analyses of geochemical samples. Anal. Chem. 72, 3116-3121.

Goñi, M.A., Ruttenberg, K.C., Eglinton, T.I., 1998. A reassessment of the sources and importance of land-derived organic matter in surface sediments from the Gulf of Mexico. Geochim. Cosmochim. Acta 62, 3055-3075.

Guan, B., Fang, G., 2006. Winter counter-wind currents off the southeastern China coast: a review. J. Oceanogr. 62, 1-24.

Guo, Z., Yang, Z., Zhang, D., Fan, D., Lei, K., 2002. Seasonal distribution of suspended matter in the northern East China Sea and barrier effect of current circulation on its transport. Acta Oceanol. Sin. (Chin. Ed.)/Haiyang Xuebao. 24, 71-80.

Hao, T., Liu, X., Ogg, J., Liang, Z., Xiang, R., Zhang, X., et al., 2017. Intensified episodes of East Asian Winter Monsoon during the middle through late Holocene driven by North Atlantic cooling events: high-resolution lignin records from the South Yellow Sea, China. Earth Planet. Sci. Lett. 479, 144-155.

Hatfield, R., 2014. Particle size-specific magnetic measurements as a tool for enhancing our understanding of the bulk magnetic properties of sediments. Minerals 4, 758 .

He, H., Yu, Z., Chen, H., Yao, Q., Mi, T., 2010. The Water Elutriator Method for Particle Size Seperation and its Application (in Chinese with English Abstract). 40. Periodical of Ocean University of China, pp. 68-72.

Hedges, J.I., Keil, R.G., 1995. Sedimentary organic matter preservation: an assessment and speculative synthesis. Mar. Chem. 49, 81-115. 
Hedges, J.I., Clark, W.A., Quay, P.D., Richey, J.E., Devol, A.H., Santos, M., 1986. Compositions and fluxes of particulate organic material in the Amazon River1. Limnol. Oceanogr. 31, 717-738.

Hsueh, Y., 2000. The Kuroshio in the East China Sea. J. Mar. Syst. 24, 131-139.

Hu, L., Shi, X., Yu, Z., Lin, T., Wang, H., Ma, D., et al., 2012. Distribution of sedimentary organic matter in estuarine-inner shelf regions of the East China Sea: implications for hydrodynamic forces and anthropogenic impact. Mar. Chem. 142-144, 29-40.

Huang, Y., Freeman, K.H., Eglinton, T.I., Alayne Street-Perrott, F., 1999. $\delta 13 C$ analyses of individual lignin phenols in Quaternary lake sediments: a novel proxy for deciphering past terrestrial vegetation changes. Geology 27, 471-474.

Huang, D., Zeng, D., Ni, X., Zhang, T., Xuan, J., Zhou, F., et al., 2016. Alongshore and crossshore circulations and their response to winter monsoon in the western East Chin Sea. Deep-Sea Res. Part II-Top. Stud. Oceanogr. 124, 6-18.

Huh, C.-A., Chen, W., Hsu, F.-H., Su, C.-C., Chiu, J.-K., Lin, S., et al., 2011. Modern $(<100$ years) sedimentation in the Taiwan Strait: rates and source-to-sink pathways elucidated from radionuclides and particle size distribution. Cont. Shelf Res. 31, 47-63.

Keil, R.G., Mayer, L.M., Quay, P.D., Richey, J.E., Hedges, J.I., 1997. Loss of organic matter from riverine particles in deltas. Geochim. Cosmochim. Acta 61, 1507-1511.

Keil, R.G., Tsamakis, E., Giddings, J.C., Hedges, J.I., 1998. Biochemical distributions (amino acids, neutral sugars, and lignin phenols) among size-classes of modern marine sediments from the Washington coast. Geochim. Cosmochim. Acta 62, 1347-1364.

Kuzyk, Z.Z.A., Goñi, M.A., Stern, G.A., Macdonald, R.W., 2008. Sources, pathways and sinks of particulate organic matter in Hudson Bay: evidence from lignin distributions. Mar. Chem. 112, 215-229.

Lee, H.-J., Chao, S.-Y., 2003. A climatological description of circulation in and around the East China Sea. Deep-Sea Res. Part II-Top. Stud. Oceanogr. 50, 1065-1084.

Li, X., Bianchi, T.S., Allison, M.A., Chapman, P., Mitra, S., Zhang, Z., et al., 2012. Composition, abundance and age of total organic carbon in surface sediments from the inner shelf of the East China Sea. Mar. Chem. 145-147, 37-52.

Li, X., Bianchi, T.S., Allison, M.A., Chapman, P., Yang, G., 2013. Historical reconstruction of organic carbon decay and preservation in sediments on the East China Sea shelf. J. Geophys. Res. Biogeosci. 118, 1079-1093.

Li, D., Yao, P., Bianchi, T.S., Zhang, T., Zhao, B., Pan, H., et al., 2014a. Organic carbon cycling in sediments of the Changjiang Estuary and adjacent shelf: implication for the influence of Three Gorges Dam. J. Mar. Syst. 139, 409-419.

Li, G., Li, P., Liu, Y., Qiao, L., Ma, Y., Xu, J., et al., 2014b. Sedimentary system response to the global sea level change in the East China Seas since the last glacial maximum. EarthSci. Rev. 139, 390-405.

Li, G., Qiao, L., Dong, P., Ma, Y., Xu, J., Liu, S., et al., 2016. Hydrodynamic condition and suspended sediment diffusion in the Yellow Sea and East China Sea. J. Geophys. Res. Oceans. 121, 6204-6222.

Lian, E., Yang, S., Wu, H., Yang, C., Li, C. Liu, JT, 2016. Kuroshio subsurface water feeds the wintertime Taiwan Warm Current on the inner East China Sea shelf. J. Geophys. Res. Oceans. 121, 4790-4803.

Lin, S., Hsieh, I.J., Huang, K.-M., Wang, C.-H., 2002. Influence of the Yangtze River and grain size on the spatial variations of heavy metals and organic carbon in the East China Sea continental shelf sediments. Chem. Geol. 182, 377-394.

Lin, T., Hu, L., Guo, Z., Zhang, G., Yang, Z., 2013. Deposition fluxes and fate of polycyclic aromatic hydrocarbons in the Yangtze River estuarine-inner shelf in the East China Sea. Glob. Biogeochem. Cycle. 27, 77-87.

Liu, J.P., Li, A.C., Xu, K.H., Veiozzi, D.M., Yang, Z.S., Milliman, J.D., et al., 2006. Sedimentary features of the Yangtze River-derived along-shelf clinoform deposit in the East China Sea. Cont. Shelf Res. 26, 2141-2156.

Liu, J.P., Xu, K.H., Li, A.C., Milliman, J.D., Velozzi, D.M., Xiao, S.B., et al., 2007. Flux and fate of Yangtze River sediment delivered to the East China Sea. Geomorphology 85, 208-224.

Liu, S., Qiao, L., Li, G., Li, J., Wang, N., Yang, J., 2015. Distribution and cross-front transport of suspended particulate matter over the inner shelf of the East China Sea. Cont. Shelf Res. 107, 92-102.

Louchouarn, P., Lucotte, M., Canuel, R., Gagné, J.-P., Richard, L.-F., 1997. Sources and early diagenesis of lignin and bulk organic matter in the sediments of the Lower St. Lawrence Estuary and the Saguenay Fjord. Mar. Chem. 58, 3-26.

Ma, C., Wu, D., Lin, X., Yang, J., Ju, X., 2010. An open-ocean forcing in the East China and Yellow seas. J. Geophys. Res. Oceans. 115, C12056.

Milliman, J.D., Beardsley, R.C., Zuo-sheng, Y., Limeburner, R., 1985a. Modern Huanghederived muds on the outer shelf of the East China Sea: identification and potential transport mechanisms. Cont. Shelf Res. 4, 175-188.

Milliman, J.D., Huang-ting, S., Zuo-sheng, Y., Mead, R.H., 1985b. Transport and deposition of river sediment in the Changjiang estuary and adjacent continental shelf. Cont. Shelf Res. 4, 37-45.

Muslim, I., Jones, G., 2003. The seasonal variation of dissolved nutrients, chlorophyll a and suspended sediments at Nelly Bay, Magnetic Island. Estuar. Coast. Shelf Sci. 57, 445-455.

Ogrinc, N., Fontolan, G., Faganeli, J., Covelli, S., 2005. Carbon and nitrogen isotope compositions of organic matter in coastal marine sediments (the Gulf of Trieste, N Adriatic Sea): indicators of sources and preservation. Mar. Chem. 95, 163-181.

Opsahl, S., Benner, R., 1995. Early diagenesis of vascular plant tissues: lignin and cutin decomposition and biogeochemical implications. Geochim. Cosmochim. Acta 59, 4889-4904.

Otto, A., Simpson, M.J., 2006. Evaluation of CuO oxidation parameters for determining the source and stage of lignin degradation in soil. Biogeochemistry 80, 121-142.

Pan, Y., 1987. Oceanographic conditions of Taiwan Warm Current area during June-July 1984. Collection of Papers on Kuroshio Survey and Research, State Oceanic Administration of China (in Chinese with English Abstract). Ocean Publisher, Beijing, China, pp. 118-132.
Peng, M., Hu, D., 1997. Outflow of suspended materials from the Changjiang River mouth. Chin. J. Oceanol. Limnol. 15, 258-263.

Qiao, F., Yang, Y., Lü, X., Xia, C., Chen, X., Wang, B., et al., 2006. Coastal upwelling in the East China Sea in winter. J. Geophys. Res. Oceans. 111, C11S06.

Qiao, L., Wang, Z., Liu, S., Li, G., Liu, X., Huang, L., et al., 2017. From continental shelf seas to the western Pacific: the path and mechanism of cross-shelf suspended sediment transport in the Yellow Sea and East China Sea(in Chinese). Earth Sci. Front. 24, 134-140.

Ren, J.-L., Xuan, J.-L., Wang, Z.-W., Huang, D., Zhang, J., 2015. Cross-shelf transport of terrestrial Al enhanced by the transition of northeasterly to southwesterly monsoon wind over the East China Sea. J. Geophys. Res. Oceans. 120, 5054-5073.

Ruttenberg, K.C., Goñi, M.A., 1997. Phosphorus distribution, C:N:P ratios, and $\delta 13 \mathrm{Coc}$ in arctic, temperate, and tropical coastal sediments: tools for characterizing bulk sedimentary organic matter. Mar. Geol. 139, 123-145.

Shan, X., Shi, X., Clift, P.D., Qiao, S., Jin, L., Liu, J., et al., 2018. Carbon isotope and rare earth element composition of Late Quaternary sediment gravity flow deposits on the mid shelf of East China Sea: implications for provenance and origin of hybrid event beds. Sedimentology https://doi.org/10.1111/sed.12561.

Stephane, H., Patrick, L., Marc, L., Rene, C., Bassam, G., 2006. Translocation of soil organic matter following reservoir impoundment in boreal systems: implications for in situ productivity. Limnol. Oceanogr. 51, 1497-1513.

Stevenson, F.J., Cheng, C.N., 1972. Organic geochemistry of the argentine basin sediments: carbon-nitrogen relationships and Quaternary correlations. Geochim. Cosmochim. Acta 36, 653-671.

Su, J., 2001. A review of circulation dynamics of the coastal oceans near China. Acta Oceanol. Sin. (Chin. Ed.)/Haiyang Xuebao. 23, 1-16.

Tareq, S.M., Tanaka, N., Ohta, K., 2004. Biomarker signature in tropical wetland: lignin phenol vegetation index (LPVI) and its implications for reconstructing the paleoenvironment. Sci. Total Environ. 324, 91-103.

Tareq, S.M., Handa, N., Tanoue, E., 2006. A lignin phenol proxy record of mid Holocene paleovegetation changes at Lake DaBuSu, Northeast China. J. Geochem. Explor. 88, 445-449.

Tareq, S.M., Kitagawa, H., Ohta, K., 2011. Lignin biomarker and isotopic records of paleovegetation and climate changes from Lake Erhai, southwest China, since 18.5 ka BP. Quat. Int. 229, 47-56.

Teisserenc, R., Lucotte, M., Houel, S., Carreau, J., 2010. Integrated transfers of terrigenous organic matter to lakes at their watershed level: a combined biomarker and GIS analysis. Geochim. Cosmochim. Acta 74, 6375-6386.

Tesi, T., Miserocchi, S., Goñi, M.A., Langone, L., 2007. Source, transport and fate of terrestrial organic carbon on the western Mediterranean Sea, Gulf of Lions, France. Mar. Chem. 105, 101-117.

Tesi, T., Langone, L., Goñi, M.A., Miserocchi, S., Bertasi, F., 2008. Changes in the composition of organic matter from prodeltaic sediments after a large flood event (Po River, Italy). Geochim. Cosmochim. Acta 72, 2100-2114.

Tesi, T., Semiletov, I., Hugelius, G., Dudarev, O., Kuhry, P., Gustafsson, Ö., 2014. Composition and fate of terrigenous organic matter along the Arctic land-ocean continuum in East Siberia: insights from biomarkers and carbon isotopes. Geochim. Cosmochim. Acta $133,235-256$

Tesi, T., Semiletov, I., Dudarev, O., Andersson, A., Gustafsson, Ö., 2016. Matrix association effects on hydrodynamic sorting and degradation of terrestrial organic matter during cross-shelf transport in the Laptev and East Siberian shelf seas. J. Geophys. Res. Biogeosci. 121, 731-752.

Vonk, J.E., Semiletov, I.P., Dudarev, O.V., Eglinton, T.I., Andersson, A., Shakhova, N., et al., 2014. Preferential burial of permafrost-derived organic carbon in Siberian-Arctic shelf waters. J. Geophys. Res. Oceans. 119, 8410-8421.

Wakeham, S.G., Canuel, E.A., Lerberg, E.J., Mason, P., Sampere, T.P., Bianchi, T.S., 2009. Partitioning of organic matter in continental margin sediments among density fractions. Mar. Chem. 115, 211-225.

Walling, D.E., Woodward, J.C., 1993. Use of a field-based water elutriation system for monitoring the in situ particle size characteristics of fluvial suspended sediment. Water Res. 27, 1413-1421.

Wang, W., Jiang, W., 2008. Study on the seasonal variation of the suspended sediment distribution and transportation in the East China Seas based on SeaWiFS data. J. Ocean Univ. China 7, 385-392.

Wang, X.-C., Sun, M.-Y., Li, A.-C., 2008. Contrasting chemical and isotopic compositions of organic matter in Changjiang (Yangtze River) estuarine and East China Sea shelf sediments. J. Oceanogr. 64, 311-321.

Wang, H., Saito, Y., Zhang, Y., Bi, N., Sun, X., Yang, Z., 2011. Recent changes of sediment flux to the western Pacific Ocean from major rivers in East and Southeast Asia. Earth-Sci. Rev. 108, 80-100.

Wang, J., Yao, P., Bianchi, T.S. Li, D. Zhao, B. Cui, X et al., 2015. The effect of particle density on the sources, distribution, and degradation of sedimentary organic carbon in the Changjiang Estuary and adjacent shelf. Chem. Geol. 402, 52-67.

$\mathrm{Wu}, \mathrm{H}$., 2015. Cross-shelf penetrating fronts: a response of buoyant coastal water to ambient pycnocline undulation. J. Geophys. Res. Oceans. 120, 5101-5119.

Wu, H., Deng, B., Yuan, R., Hu, J., Gu, J., Shen, F., et al., 2013. Detiding measurement on transport of the Changjiang-derived buoyant coastal current. J. Phys. Oceanogr. 43, 2388-2399.

Wu, J., Ren, J., Liu, H., Qiu, C., Cui, Y., Zhang, Q., 2015. Trapping and escaping processes of Yangtze River-derived sediments to the East China Sea. Geol. Soc. Lond., Spec. Publ. 429 .

Xu, K., Milliman, J.D., Li, A., Paul Liu, J., Kao, S.-J., Wan, S., 2009. Yangtze- and Taiwan-derived sediments on the inner shelf of East China Sea. Cont. Shelf Res. 29, 2240-2256.

Xu, K., Li, A., Liu, J.P., Milliman, J.D., Yang, Z., Liu, C.-S., et al., 2012. Provenance, structure, and formation of the mud wedge along inner continental shelf of the East China Sea: a synthesis of the Yangtze dispersal system. Mar. Geol. 291-294, 176-191. 
Yanagi, T., Takahashi, S., Hoshika, A., Tanimoto, T., 1996. Seasonal variation in the transport of suspended matter in the East China Sea. J. Oceanogr. 52, 539-552.

Yang, D., Yin, B., Liu, Z., Feng, X., 2011. Numerical study of the ocean circulation on the East China Sea shelf and a Kuroshio bottom branch northeast of Taiwan in summer. J. Geophys. Res. Oceans. 116, C05015.

Yang, D., Yin, B., Liu, Z., Bai, T., Qi, J., Chen, H., 2012. Numerical study on the pattern and origins of Kuroshio branches in the bottom water of southern East China Sea in summer. J. Geophys. Res. Oceans. 117, C02014.

Yao, P., Zhao, B., Bianchi, T.S., Guo, Z., Zhao, M., Li, D., et al., 2014. Remineralization of sedimentary organic carbon in mud deposits of the Changjiang estuary and adjacent shelf: implications for carbon preservation and authigenic mineral formation. Cont. Shelf Res. 91, 1-11.

Yao, P., Yu, Z., Bianchi, T.S., Guo, Z., Zhao, M., Knappy, C.S., et al., 2015. A multiproxy analysis of sedimentary organic carbon in the Changjiang Estuary and adjacent shelf. J. Geophys. Res. Biogeosci. 120, 1407-1429.

Ying, W., Timothy, E., Liyang, Y., Bing, D., Daniel, M., Jing, Z., 2013. Spatial variability in the abundance, composition, and age of organic matter in surficial sediments of the East China Sea. J. Geophys. Res. Biogeosci. 118, 1495-1507.

Yuan, D., Zhu, J., Li, C., Hu, D., 2008. Cross-shelf circulation in the Yellow and East China Seas indicated by MODIS satellite observations. J. Mar. Syst. 70, 134-149.

Zeng, D., Ni, X., Huang, D., 2012. Temporal and spatial variability of the ZheMin coastal current and the Taiwan warm current in winter in the southern Zhejiang coastal sea (in Chinese). Sci. China-Earth Sci. 42, 1123-1134.

Zhang, L., Zhang, J., Gong, M., 2009. Size distributions of hydrocarbons in suspended particles from the Yellow River. Appl. Geochem. 24, 1168-1174.
Zhang, L.J., Wang, L., Cai, W.J., Liu, D.M., Yu, Z.G., 2013a. Impact of human activities on organic carbon transport in the Yellow River. Biogeosciences 10, 2513-2524.

Zhang, T., Li, X., Sun, S., Lan, H., Du, P., Wang, M., 2013b. Determination of lignin in marine sediment using alkaline cupric oxide oxidation-solid phase extraction-on-column derivatization-gas chromatography. J. Ocean Univ. China 12, 63-69.

Zhou, F., Xue, H., Huang, D., Xuan, J., Ni, X., Xiu, P., et al., 2015. Cross-shelf exchange in the shelf of the East China Sea. J. Geophys. Res. Oceans. 120, 1545-1572.

Zhou, P., Song, X., Yuan, Y., Cao, X., Wang, W., Chi, L., et al., 2018. Water mass analysis of the East China Sea and interannual variation of Kuroshio subsurface water intrusion through an optimum multiparameter method. J. Geophys. Res. Oceans. 123, 3723-3738.

Zhu, J., Chen, C., Ding, P., Li, C., Lin, H., 2004. Does the Taiwan warm current exist in winter? Geophys. Res. Lett. 31, L12302.

Zhu, C., Wagner, T., Pan, J.M., Pancost, R.D., 2011a. Multiple sources and extensive degradation of terrestrial sedimentary organic matter across an energetic, wide continental shelf. Geochem. Geophys. Geosyst. 12.

Zhu, C., Wang, Z.-H., Xue, B., Yu, P.-S., Pan, J.-M., Wagner, T., et al., 2011b. Characterizing the depositional settings for sedimentary organic matter distributions in the Lower Yangtze River-East China Sea Shelf System. Estuar. Coast. Shelf Sci. 93, 182-191.

Zhu, C., Wagner, T., Talbot, H.M., Weijers, J.W.H., Pan, J.-M., Pancost, R.D., 2013. Mechanistic controls on diverse fates of terrestrial organic components in the East China Sea. Geochim. Cosmochim. Acta 117, 129-143. 